\title{
Effect of Government Interventions on Primary School Pupils' Enrolment and Retention in Kotido District, Uganda
}

\author{
Victoria A. Namukwaya \\ Bugema University, Graduate School, \\ Department of Development Studies, Kampala, Uganda \\ Israel Kibirige \\ University of Limpopo, School of Education. Department of Mathematics, \\ Science \& Technology Education (DMSTE), South Africa \\ Corresponding author: Israel.Kibirige@ul.ac.za
}

\section{Doi:10.5901/mjss.2014.v5n8p354}

\section{Abstract}

\begin{abstract}
Attainment of basic education is one of the most effective processes towards improving human capital for social and economic development. In order to ensure educational attainment, numerous interventions have been designed globally and at national levels. This study investigated the effect of selected government interventions $(G /)$ on enrolment and retention of pupils in primary schools in Kotido district in Uganda. The study employed a quantitative approach and a correlational design. Data were collected from 78 participants using a semi-structured questionnaire. In addition, document analysis was used to collect enrolment data from schools and the District Education Office. Data were analysed using descriptive and inferential statistics. The results show that district gross enrolment increased by $55.4 \%$ but gross enrolment accounted for less than half of the number of school-age children and the retention ratio was less than 10\%. There was no significant correlation between government interventions and enrolment as well as retention. These findings suggest that the effective participation of Karimojong children in the development process will remain low unless the government strengthens the existing interventions and designs new strategies to improve education attainment.
\end{abstract}

Keywords: Government interventions, development, education, enrolment and retention

\section{Introduction}

Attainment of education is critical to development and social justice and this makes enrolment and retention of children in schools an issue of global concern as highlighted in Millennium Development Goal (MDG) Number 2. The Education for All (EFA) Global Monitoring Report 2012, however, indicates that sixty-one million children of primary school age were not enrolled in schools and that many that enrol drop out early and do not reach minimal learning standards (UNESCO, 2012). Balfanz and Legters (2004) point out that whereas it is desirable that children should remain in school until graduation, many children continue to leave school. Moreover, Maton and Moore (2010) argue that dropping out of school should be the concern of every member of society, since it has negative consequences not only to the individual but on society as a whole. It is on this premise that different governments design interventions to ensure that children can enrol and keep in school. Education attainment is a concern to both developed and developing countries. The United States of America government for instance, decreed the "No Child Left Behind" Act 2001, which commitment President Obama reaffirmed in his Inauguration Speech, that "every American will need to get more than a high school diploma and that dropping out was no longer an option" (Obama 2009). From President Obama's statement, USA is not targeting to have her citizens acquire basic education but to attain more than a high school diploma.

For sub-Saharan Africa, the EFA Global Monitoring Report (UNESCO, 2010) indicates that significant progress towards universal primary education has been made; with Net Enrolment Ratio (NER) of 73\%. NER is the enrolment of the official age group for a given level of education expressed as a percentage of the population in that age group. The same report, however, points out that the average education for Karimojong pastoralists is less than one year (UNESCO, 2010). Thus, whereas there are big strides towards improving access to education in Uganda there are regional differences in education attainment.

Improved access to education has been done through universalisation of primary education which has benefited 
many children who could not attend school because of cost. For instance in Uganda, universalisation of primary education in 1997 increased primary school enrolment from 2.7 million in 1997 to 8.2 million in 2009 (Republic of Uganda, 2010). According to Uganda Universal Primary Education (UPE) Policy, primary school level education consisting of seven years of school is compulsory and free. While the enrolment statistics above show that the introduction of UPE improved gross enrolment dramatically, the aggregate report obscures regional disparities. Even with free education, attainment has remained low, manifesting regional and sex-based imbalances. For instance, Karamoja literacy level is estimated at only 11\% (United Nations Office for the Coordination of Humanitarian Affairs [UNOCHA], 2009) compared to the national literacy rate of 88\% (Ministry of Finance, Planning and Economic Development [MFPED], 2010). The current geographical Kotido district has been in existence since 2006 after carving-out Kaabong and Abim districts. The district seems to be greatly affected by low enrolment and retention with NER of 31\% for 2011/2012 and completion ratio of 12\% (MoES, 2012). This low enrolment and retention has necessitated various government interventions (GI) to ensure that all children can access basic education.

\section{Statement of the problem}

Notwithstanding the successful story of UPE in increasing access to education in Uganda, the enrolment and retention profiles remain skewed across the country. Kotido district, for instance, still records NER of $31 \%$ and a completion ratio of $12 \%$ (MoES, 2012). These ratios indicate that enrolment and retention is still a big challenge resulting in low education attainment in the district. Due to low education attainment, the district registers one of the lowest literacy levels in the country and lags behind in all development indicators (UNOCHA, 2009). If Kotido district continues to lag behind in enrolment and retention, then Uganda's dream of achieving MDG Number 2 and the National Vision of 'a modern and prosperous country by 2040' (Government of Uganda, 2013) will be disillusioned. In order to improve education attainment in Kotido district, the government of Uganda initiated interventions geared at promoting enrolment and retention of pupils in primary schools. There is however scanty literature on the effect of these interventions on enrolment and retention of pupils in schools. Therefore this study investigated the effect of selected GI (independent variable) on enrolment and retention (dependent variables) of pupils in primary schools in Kotido district.

\section{The purpose of the study}

The purpose of the study was to: 1) ascertain enrolment and retention rates of pupils in primary schools in Kotido district; and 2) find out the relationship between $\mathrm{Gl}$ and enrolment as well as retention of pupils in primary schools in Kotido district.

\section{Hypothesis}

The GI (school supply, school funding, School Management Committees (SMCs), school feeding, and Alternative Basic Education for Karamoja (ABEK) do not significantly affect enrolment and retention of pupils in primary schools in Kotido district.

\section{Theoretical Framework}

The study was conceived within Schultz's (1961) Human Capital theory and the Functionalist theory by Merton (1968). The Human Capital theory postulates that knowledge and skills are a form of capital that leads to increased human productivity (Schultz, 1961), while the Functionalist theory focuses on ways that universal education serves the needs of society (Durkheim, 1915). Actually, functionalists address: "society as a whole in terms of the function of its constituent elements; namely norms, customs, traditions, and institutions" (Urry, 2000 p. 23). Functionalists further contend that education is a process of conveying basic knowledge and skills to the next generation (Ebaugh, 1988). Durkheim (1915) identified the latent role of education as one of socializing people into society's mainstream. This socialization helps to form a more-cohesive social structure by bringing together people from diverse backgrounds (Durkheim, 1915). In line with the Human Capital and Functionalist theories, a number of interventions have been designed to integrate the people of Karamoja into the general Ugandan economy through improving enrolment and retention of pupils in primary schools. 


\section{Literature Review}

Low enrolment and retention of pupils in schools is a fundamental obstacle towards achievement of Education for All as many children remain out of school and the ones who enrol do not complete primary education. In Uganda, the state is the prime provider of education services. Thus, Uganda government has committed a lot of resources and put in place various interventions to ensure that children can attain basic education. Some of these interventions are at national level while others are specific to regions. Regardless of Uganda Government's good will to ensure access to basic education by all children in the country, it is evident that not all children from the different parts of the country have benefited. Due to the uniqueness of Karamoja region, a number of interventions have been designed to address the inequalities of access to basic education. These include among others: ensuring school supply, school funding, School Management Committees, School feeding and the Alternative Basic Education for Karamoja (ABEK).

\subsection{School supply}

School supply means making schools available and functional; which implies availability of school buildings, hiring teachers, as well as providing an enabling environment to motivate the teachers to teach. Making schools available is part of the state's commitment to fulfill the fundamental rights of all Ugandans to social justice and economic development by ensuring that all Ugandans enjoy rights, opportunities and access to education (Government of Uganda, 1995). According to Uganda Human Rights Commission (UHRC Report, 2004), the obligation to establish sufficient schools, hire required teachers and provide quality education is the responsibility of the state. In the case of Kotido district which is rated as a hard-to-reach area; characterised by poor social services and insecurity, teachers' accommodation is a vital aspect of school supply. A study by Diyu (2002), for instance, points out that teachers' motivation and absenteeism were correlated with pupil drop out. A school without teachers will serve no purpose.

Schools can benefit target communities when they are accessible. Studies have shown that distance can be a barrier to children enrolling and continually attending school. For instance, a study by Akresh (2008) in four African countries namely; Malawi, Nigeria, Uganda and Zambia revealed a negative relationship between gross attendance and distance. In three of the four countries attendance rates declined as distance to school increased, with steep decline recorded in Nigeria (Akresh, 2008). Other studies by Glick \& Sahn (2006), Colclough et al. (2000) and Ainsworth et al. (2005) also show that long distance has a negative impact on attending school.

\subsection{School funding}

In addition to ensuring school supply, Kailembo (2000) argues that provision of necessary inputs is critical to ensuring quality education. Schools, like any other public institutions, need financial resources in order to be functional. The responsibility to finance education is a joint venture between parents and the state in order to support infrastructure, school fees scholastic materials and teachers' salaries. In Uganda, payment of school fees was abolished in 1997, and since then, Education sector allocations are reported to have increased from 250 billion Uganda Shillings in 1997/98 to 899.3 billion in 2008/9 (Overseas Development Institute [ODI]/Mokoro, 2008). Despite the increase in budget allocations to the education sector, Uwezo's Annual Learning Assessment Report 2010, points out that the allocation is not adequate and it is not disbursed in time, which undermines the quality of education.

\subsection{School Management Committees}

The role of School Management Committees (SMCs) is to ensure that schools are closely linked to communities for maximum benefit and accountability of resources (Ministry of Education \& Sports [MoES], 2008). Wajdi (WB, 2010), uses the experience in Afganistan to point out the potential for SMCs to improve enrolment in schools. Likewise, in a study conducted in Mali, Laugharn (2007), points out that SMCs can exert a lot of influence in getting children to enrol in school, particularly since the members are elected from communities surrounding the schools and as such provide immediate interface between the school and the community. Similarly, Takahashi \& Narahara (2009) report improvement in school enrolment rate in Niger from around 50\% in 2004, to around 68\% in 2009 as a result of strengthening the SMCs. The role of SMCs is not only limited to improving enrolment but it also involves ensuring proper resource mobilisation and utilisation. A study in South Africa pointed out that equipping members of the school governing bodies ('SGBs in South African context') with financial management skills improves overall quality of teaching and learning in the schools (Mestry, 2004; Marishane, 2013). SMCs are able to influence community participation which translates into improved utilisation of 
the education services. In Uganda, improving the SMCs participation by use of participatory score cards reduced teachers' and pupils' absenteeism and improved overall learning outcomes (Zeitlin et al, 2011).

\subsection{School feeding}

School feeding is recognised globally as a key strategy towards accelerating attainment of basic education. The World Food Programme's school feeding programmes, for instance, work towards reducing hunger by half and achieving Universal Primary Education by 2015, as well as achieving gender parity in Education (World Food Programme, 2010). Serving food in school helps to get children into school. A meta-analysis of 32 sub-Saharan African countries carried out by Gelli, et al. (2007) concluded that school feeding is associated with increased enrolment. Whereas the literature cited above highlights the effect of school feeding on enrolment and retention of pupils in schools, there are no published experiences from Karamoja region.

\subsection{Alternative Basic Education for Karamoja}

Kratli (2000) stresses that attaining education provides the beneficiaries with an opportunity for their full accomplishment as human beings. Whereas attending primary schools is the formal way to accessing basic education, there are unique situations where alternative programs have been designed. International Institute for Educational Planning, IIEP (2006) assert that non-formal education expands access to education to people from diverse backgrounds. Some of such programs in Uganda are the Complementary Opportunities for Primary Education (COPE) and Alternative Basic Education for Karamoja (ABEK) which provide opportunities to disadvantaged children to access education. The ABEK programmr was launched to address pastoral lifestyle challenges that limited Karimojong children to benefit from the formal education system (Chelimo, 2005). One of the objectives of the ABEK programme was to increase enrolment, inclusiveness, retention and astuteness of Karimojong children enrolled for basic education. The ABEK programme was meant to introduce Karimojong children to education by arousing their interest in education, which would later persuade them to join formal school.

While various authors (Glick \& Sahn, 2006; Laugharn, 2007; Gelli, et al. 2007) highlight the effect of different interventions in improving access to basic education, the effects of such interventions in Kotido district are not well documented. On the other hand, evaluation of such interventions often employs Sector Wide Approaches such as national evaluations and as such very little is known about the effectiveness of specific interventions at regional and operational levels (Penny et al., 2008). Thus, most of the available literature on the effect of various interventions lacks the Karamoja context. This gap necessitated this study to find out the effect of $\mathrm{Gl}$ on enrolment and retention of pupils in Karamoja region with specific reference to Kotido district.

\section{Methodology}

\subsection{Research Design}

The study employed a descriptive and correlational research design in order to investigate the effect of $\mathrm{GI}$ on enrolment and retention of pupils in schools and to establish the relationships between the various $\mathrm{Gl}$ and enrolment and retention of pupils in primary schools.

\subsection{Study Participants}

The study targeted four different categories of respondents, namely: head teachers, classroom teachers, parents, and opinion leaders in Kotido district. The choice of categories of respondents was based on recognising them as key stakeholders in the implementation of the specific interventions already outlined in the preceding segment. The study participants were 78, comprising: 8 head teachers, 28 classroom teachers, 36 parents and 6 opinion leaders. The selection of the schools was simple random sampling to avoid bias. The names of the primary schools in each sub county were written on separate pieces of paper and the papers were placed in different bowls. The blindfolded researcher then picked two papers from each bowl which resulted in 8 names of schools that became part of the sample. All 8 head teachers of the selected schools participated in the study. Teachers were selected based on their availability at school at the time of data collection. Purposeful sampling was used to select the opinion leaders as the researchers deemed them to have significant information about the interventions. Convenient sampling was used to select parents. The respondents 
were drawn from 4 sub counties: Kotido 20, Rengen 20, Kacheri 20 and Panyangara 18.

\subsection{Validity and Reliability}

The research instrument was checked for clarity and consistency to ensure content and construct validity. The instrument whose validity had been assured was pre-tested in two primary schools and two communities in Kotido District, which were not included in the study. From the pre-testing, there were some questions that were rephrased to make them clearer. The Content Validity Index (CVI) of the instrument was calculated by dividing the number of items judged right by the total number of items in the questionnaire. The CVI of the instrument was 0.77 . To ensure reliability, a Percentage Agreement for Reliability was employed where the pre-tested questionnaires were given to two teachers to test for sequence, clarity, relevance and each was scored on a 3 point scale and the percentage agreement between the two teachers was 89 suggesting that the questions had acceptable reliability. The two teachers were not part of the respondents in the study.

\subsection{Data Collection}

A semi-structured self-administered questionnaire was used to obtain data from head teachers, classroom teachers and opinion leaders. The instrument was additionally used as an interview schedule for parents since the majority were not able to read and write. The questionnaire comprised of 19 questions which were scored on a five-point Likert scale that ranged from 1 to 5: 1 Strongly Disagree, 2 Disagree, 3 Somewhat Agree, 4 Agree and 5 Strongly Agree. Document analysis was employed to review records at the District Education Office as well as enrolment records in the respective schools. Data were also obtained from the district statistics office on district projections for school-age children (6-12 years) for five successive years (2006-2010) in order to compute the enrolment ratios of the current geographical Kotido district. Enrolment figures for all classes were collected from the eight schools for the year 2010. Retention data were obtained from only 6 schools which had Primary Seven (P.7) so that enrolment data were obtained for pupils in Primary One (P.1) and later followed to see how many reached P.7 in seven years' time (2004-2010). A document review guide was constructed with themes to guide collection of data on enrolment and retention from both the District Education office and the schools.

\subsection{Data Analysis}

Data collected were analysed using descriptive and inferential statistics. For descriptive statistics: frequencies, percentages, means and ratios were used, while for inferential statistics Pearson's Product Moment Correlation was used to establish the relationship between $\mathrm{GI}$ mean ratings and enrolment and retention ratios at $p<0.05$. All data analysis was done using SPSS Version 20.

\section{Results}

The results show that there was $55.4 \%$ increase in enrolment, although gross enrolment accounted for less than half of the number of school-age children and average retention ratio was less than $10 \%$. The results also indicate a low to moderate positive correlation, though not significant, between $\mathrm{Gl}$ and enrolment as well as retention. Detailed results are presented in two subsections as: Enrolment and Retention Ratios and Correlations between $\mathrm{Gl}$ and enrolment as well as retention.

\subsection{Enrolment and Retention Ratios}

To ascertain enrolment and retention ratios of pupils in primary schools, gross enrolment data were collected from Kotido District Education office for a period of five years. In addition, district population projections were obtained from the District Statistics Office for the number of school-age children during 2006 to 2010 and details are presented in Table 1. Gross Enrolment Ratio (GER) was computed by dividing the total enrolment by the population projection for the 6-12 year old children (school-age) multiplied by 100. It can be seen that total enrolment of pupils in primary schools rose from 11521 (5827 boys, 5694 girls) in 2006 to 17905 (10504 boys, 7401 girls) in 2010. The lowest GER of 36.8 was recorded in 2007 and the highest of 43.9 was recorded in 2009. 
Table 1. District Projection of 6-12 years, Primary School Enrolment for 5 years and Gross Enrolment Ratios

\begin{tabular}{|c|c|c|c|c|c|c|c|c|}
\hline Year & $\begin{array}{c}\text { Gross } \\
\text { enrolment } \\
\text { (Boys) }\end{array}$ & $\%$ & $\begin{array}{c}\text { Gross } \\
\text { enrolment } \\
\text { (Girls) }\end{array}$ & $\%$ & $\begin{array}{c}\text { Total } \\
\text { Enrolment }\end{array}$ & $\%$ & $\begin{array}{c}\text { Population } \\
\text { Projection } \\
\text { 6-12yrs }\end{array}$ & $\begin{array}{c}\text { Gross } \\
\text { Enrolment } \\
\text { Ratio }\end{array}$ \\
\hline 2006 & 5827 & 50.6 & 5694 & 49.4 & 11521 & 100 & ND & ND \\
\hline 2007 & 6409 & 51.6 & 6002 & 48.4 & 12411 & 100 & 33750 & 36.8 \\
\hline 2008 & 8271 & 57.7 & 6065 & 42.3 & 14336 & 100 & 34431 & 41.6 \\
\hline 2009 & 9701 & 57.8 & 7080 & 42.2 & 16781 & 100 & 38178 & 43.9 \\
\hline 2010 & 10504 & 58.7 & 7401 & 41.3 & 17905 & 100 & 42477 & 42.2 \\
\hline Average & & 55.3 & & 44.7 & & & & 41.1 \\
\hline
\end{tabular}

ND represents: No data available

Source: Kotido District Education and Statistics offices 2010

Figure 1 gives a comparison between primary school gross enrolment and expected enrolment in Kotido district for four years.

Figure 1. Comparing Gross Enrolment with the Expected Enrolment for 4 years

Source: Kotido District Education and Statistics offices 2010

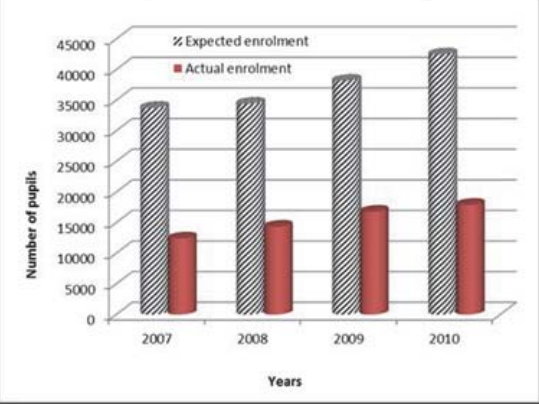

\subsection{Retention ratios}

To ascertain retention ratios, historical enrolment data were collected from six of the 8 schools involved in the study which had P.7. Enrolment data were collected for P.1 for Year 2004 and P.7 for year 2010 when the pupils enrolled in 2004 were expected to have reached P.7. Retention ratios were computed by taking enrolment figures from each school for P.1 enrolment for 2004 for both boys and girls and the corresponding P.7 enrolment for 2010 (Table 2). Although the study did not consider repetition rates and transfers in and out of the schools, it is apparent from Table 2 that a big proportion of pupils who enrolled in P.1 did not reach P.7, indicating a very low retention ratio ranging between $2.9 \%$ and $16.7 \%$ in the sampled schools. Average retention ratio was $8.2 \%$.

Table 2. Enrolment and Retention ratios for Six Schools for 2004 and 2010

\begin{tabular}{|c|c|c|c|c|c|c|c|}
\hline School & \multicolumn{3}{|c|}{ P.1 (2004) } & \multicolumn{3}{c|}{ P.7 (2010) } & Retention Ratio \\
\hline & Boys & Girls & Total & Boys & Girls & Total & \\
\hline School 1 (S1) & 309 & 211 & 520 & 12 & 3 & 15 & 2.9 \\
\hline School 2 (S 2) & 108 & 107 & 215 & 24 & 10 & 34 & 15.8 \\
\hline School 3 (S 3) & 48 & 78 & 126 & 9 & 12 & 21 & 16.7 \\
\hline School 4 (S4) & 190 & 196 & 386 & 15 & 9 & 24 & 6.2 \\
\hline School 5 (S 5) & 179 & 128 & 307 & 18 & 12 & 30 & 9.8 \\
\hline School 6 (S 6) & 206 & 285 & 491 & 27 & 14 & 41 & 8.4 \\
\hline Average & $\mathbf{1 7 3}$ & $\mathbf{1 6 8}$ & $\mathbf{3 4 1}$ & $\mathbf{1 8}$ & $\mathbf{1 0}$ & $\mathbf{2 8}$ & $\mathbf{8 . 2}$ \\
\hline
\end{tabular}

Source: Enrolment data from schools registers, Kotido district, Uganda 
Table 2 shows that all the 6 schools had high enrolment figures in P.1 ranging between 126 in School 3 and 520 in School 1 but enrolment figures dropped drastically by P.7 to 21 and 15 in the same schools. The retention ratios thus ranged from 2.9 in School 1 to 16.7 in School 3, with an average retention ratio of 8.2.

Enrolment data for 2010 collected from the 8 schools is represented in Figure 2. The results indicate that there are many children enrolled in Primary 1 but there is a drastic drop in enrolment between one class and the next. This is particularly seen to be the case between P.1 and P.3 and girls dropped out more than the boys (Figure 2).

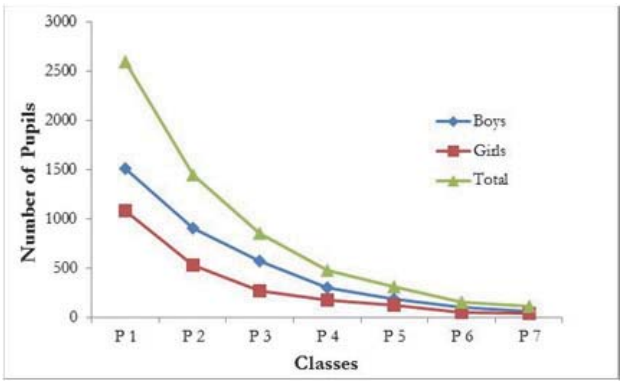

Figure 2. Enrolment trend for 8 schools

Table 3 indicates the respondents' mean ratings of the effect of various $\mathrm{GI}$ in respect to enrolment and retention of pupils. The results from the respondents indicate overall mean ratings of 3.47 for school supply, 4.08 for school funding, 3.87 for SMCs, 4.75 for school feeding and 3.44 for ABEK. The grand mean rating for GI was thus 3.92 signifying that the specific interventions had a high effect on enrolment and retention ratios.

Table 3. Mean Statistics from questionnaire on various $\mathrm{Gl}$.

\begin{tabular}{|l|c|c|}
\hline Intervention & Mean rating & Interpretation \\
\hline School supply & 3.47 & High effect \\
\hline School funding & 4.08 & High effect \\
\hline SMCs & 3.87 & High effect \\
\hline School Feeding & 4.75 & Very high effect \\
\hline ABEK & 3.44 & High effect \\
\hline Average & 3.92 & High effect \\
\hline
\end{tabular}

\subsection{Correlations between $\mathrm{Gl}$ and enrolment as well as retention}

In order to test the Hypothesis, a Pearson's Product Moment Correlation Coefficient was computed to find the relationship between $\mathrm{Gl}$ and enrolment and retention of pupils in schools. The correlation results are presented in Table 4.

Table 4. Correlations between GI and Enrolment; and GI and retention.

\begin{tabular}{|c|c|c|c|c|c|}
\hline Independent variable & Dependent variable & $\mathbf{N}$ & Pearson Correlation & $\mathrm{p}$-value) & Interpretation \\
\hline $\mathrm{Gl}$ & Enrolment & 78 & .308 & .692 & Not significant $(\mathrm{p}>0.05)$ \\
\hline $\mathrm{Gl}$ & Retention & 78 & .555 & .253 & Not significant $(\mathrm{p}>0.05)$ \\
\hline
\end{tabular}

Table 4 shows that the correlation between $\mathrm{GI}$ and enrolment of pupils in schools is: $r=.308, \mathrm{~N}=78, \mathrm{p}=.692$; while the correlation between $\mathrm{Gl}$ and retention of pupils in schools is: $r=.555, \mathrm{~N}=78, \mathrm{p}=.253$.

\section{Discussion}

The purpose of the study was to ascertain the enrolment and retention ratios and to find out the relationship between $\mathrm{Gl}$ and enrolment as well as $\mathrm{Gl}$ and retention of pupils in primary schools in Kotido district. The discussion below is divided into two sections: enrolment and retention ratios, and the relationship between $\mathrm{Gl}$ and enrolment as well as retention. 
Whereas there is a 55.4\% increase in enrolment of pupils between 2006 and 2010, there are gender disparities in favour of boys (Table 1). This can be attributed to traditional practices of a patriarchal set-up where males and females are not treated equally. Since females are not expected to make decisions in society, but to accept guidance from males, many girls are not given a chance to enrol in school.

The obtained GER of less than 50\% (Figure 1) when compared to national Net Enrolment Ratio (NER) of 96\% suggests that there is low enrolment in Kotido district. Considering the fact that among the enrolled pupils were children outside the primary school-age bracket (6-12 years), the NER would therefore be far lower than the calculated GER indicated in Table 1. This trend can partly be explained in terms of the pastoral nomadic lifestyle. This type of lifestyle involves children herding livestock and frequent movements in search of pastures and water which makes it difficult for children to enrol and keep in school. This state of affairs is worrying because the majority of school-age children are not in school. According to Kratli (2000), it may be concluded that many children in Kotido district are missing the opportunity for human capital development and for full realisation of their own destinies. This observation frustrates both the human capital theory (Schultz, 1961) and the functionalist theory (Merton, 1968) where attaining education improves ones chances to participate in development processes.

Retention in schools is a challenge as most pupils enrolled do not complete primary school. For instance, in School 1 which had an enrolment of 520 pupils in P.1, only $15(2.9 \%)$ of pupils reached P.7, while the highest retention ratio was recorded in School 3 where out of 126 pupils enrolled in P.1, 21(16.7\%) reached P.7 (Table 2). The overall retention from the six schools was $8.2 \%$ which is very low when compared to the national value of $54 \%$ (UDHS, 2010). This can be attributed to the people's nomadic pastoral lifestyle and socio-cultural characteristics. This is in agreement with Chelimo's (2005) observation that the nomadic lifestyle poses challenges to formal education. The findings may also call for a special study on the effect of the school environment on enrolment and retention of pupils in schools, which this study did not specifically address. It may be possible that more interventions may be necessary to make schools more attractive for Karimojong children.

The greatest drop was from P.1 to P. 3 (lower primary) and this resulted in very few pupils in P.4 to P.7 (upper primary). This finding may be due to the fact that by P.3 a child is considered big enough to participate in work: grazing animals and other household work. It is worthy to note that generally, more girls than boys drop out before reaching P. 7 (Table 2, Figure 2). The low enrolment and retention trend suggests that very few girls attain basic education and this implies that the majority of girls in Kotido district are missing the chance to develop their human capital and thus their productivity will remain limited which will plunge them in a state of vulnerability. Failure for Karamojong children to acquire basic education will limit their potential for integration in the mainstream society as proposed by the functionalists' theory (Ebaugh, 1988). This integration is particularly critical in this globalisation era.

Among the various $\mathrm{Gl}$, school feeding was rated to have the highest effect with a mean rating of 4.75 (Table 3). This is understandable considering the fact that Kotido district is located in a semi-arid area which is prone to food insecurity. So, providing food in schools provides a short term relief to parents' pressure to feed their children. This is in agreement with the findings by Gelli et al. (2007) where school feeding was associated with increased enrolment. This could have influenced the high enrolment in P.1 as some under-age children were being sent to school merely to access a meal.

Furthermore, the positive correlations between $\mathrm{Gl}$ and enrolment as well as retention (Table 4) may mean that the various $\mathrm{GI}$ in this study have potential to improve enrolment and retention of pupils in schools in Kotido district. If strengthened they may be able to produce significant results. For example, studies by Gelli et al. (2007) from 32 countries of sub-Saharan Africa on school feeding, and Takahashi \& Narahara (2009) on SMCs in Niger show positive correlations with enrolment. This may imply that, strengthening the GI by: improving school supply, ensuring efficient utilisation of the resources available to the schools, capacity building of the members of the SMCs so that they understand their roles, as well as ensuring efficient delivery of the ABEK programme may produce more positive effects on enrolment and retention of pupils in schools.

\section{Conclusion}

The results of the study established that enrolment and retention in Kotido district has been steadily increasing in the five years but more than half of the school-age children are not yet enrolled in school. The results further indicate an average retention ratio of only $8.2 \%$. The results further indicate that the selected GI have a weak positive relationship $(r=.308)$ to enrolment and a medium strength positive relationship ( $r=.555)$ to retention of pupils in schools (Table 4). This implies that the different $\mathrm{Gl}$ aimed at improving access to education in Kotido district had some positive effects on both enrolment and retention although the effect was not found to be statistically significant. This may be due to the small sample used in 
the study. The results could also mean that the various interventions need strengthening in order to have more significant effects. Otherwise, low education attainment by the people of Kotido district will leave the people in long-term economic marginality, which needs to be addressed as a matter of urgency. On the basis of the results of this study, strengthening the respective $\mathrm{GI}$ can produce more significant effects on enrolment and retention of pupils in primary schools in Kotido district. This calls for further studies on the effective implementation of the respective interventions. Finally, the results of this study cannot be generalized to all parts of Kotido district due to the sample size of 78 used; nevertheless, the findings form a base for further research.

\section{References}

Ainsworth, M., Beegle, K. \& Koda, G. (2005). The impact of adult mortality and parental deaths on primary schooling in North-Western Tanzania. The Journal of Development Studies, 41(3): 412-439.

Akresh, R. (2008). School enrolment impacts of non-traditional household structure. University of Illinois at Urbana-Champaign. Https://netfiles.uiuc.edu/ akresh/www /research /akresh_schoolenrollment.pdf accessed: August 15, 2010.

Balfanz, R, Legters, N. (2004). Locating the Crises: Which High Schools Produce the Nations Dropouts? Where are they located? Who Attends Them? New Jersey: Englewood Cliffs.

Chelimo, N. ABEK News (2005). A community initiative to education of pastoralists in Uganda: the Karamoja Case. Nomadic News, 10: 1-11.

Colclough, C., Rose, P. \& Tembon, M. (2000). Gender inequalities in Primary Schooling: The Roles of Poverty and adverse Cultural Practice. International Journal of Education Development, 20(1): 5-29.

Diyu, X., (2002). Investigation and discussion on the problem of primary schools dropout in poor areas. Chinese Education and Society, 33(5), 49-58.

Durkheim, E., (1915). The Elementary Forms of the Religious Life: A Study in Religious Sociology. Translated by Joseph Ward Swain. New York: Macmillan.

Ebaugh, H. R. F. (1988). Becoming an Ex: The Process of Role Exit. 1'st Ed. Chicago: University of Chicago Press.

Gelli, A., Meir U., \& Espejo, F. (2007). "Does provision of food in school increase girls' enrolment? Evidence from schools in sub Saharan Africa". Food and Nutrition Bulletin 28.

Glick, P., \& Sahn, D.E. (2006). "The demand for primary schooling in Madagascar: Price, quality, and the choice between public and private providers. Journal of Development Economics, 79(1), 118-145.

Government of Uganda (1995). The Constitution of the Republic of Uganda, Kampala. http://en.wikisource.org/wiki /Constitution_of_the_Republic_of_Uganda. Accessed July 20, 2010.

International Institute for Educational Planning, IIEP (2006). Non Formal Education. http://www.iiep.unesco.org/fileadmin /user_upload/Research_Highlights_Emergencies/Chapter12.pdf Accessed: September 23, 2013.

Kailembo, S. (2000). The prospects for improving primary school education quality. In C. J. Galabawa, F.E.M.K. Senkoro \& A. F. Lwaitama (eds.): The quality of education in University of Dar es Salaam Tanzania (pp. 145-153). Dar es Salaam: Faculty of Education.

Kratli, S. 2000). Education provision to nomadic pastoralists: A Literature Review. New York: World Bank Publication.

Laugharn, P. (2007). Negotiating 'Education for many' Enrolment, Drop out and Persistence in Community Schools of Kolondieba, Mali. CREATE Pathways to Access. Research Monograph No. 14.

Maton, K., \& Moore, R (2010). Social Realism, Knowledge and the Sociology of Education: Coalitions of the Mind .London: Routledge.

Marishane, R. N. (2013). Empowerment and accountability in implementing a 'No-Fee School' policy: A challenge for School Governing Bodies, Africa Education Review, 10:2, 224-237.

Merton, R. K. (1968). Social Theory and Social Structure. New York: Free Press.

Mestry, R. (2004). Accountability:The Principal or School Governing Body. South African Journal of Education, 24:126-132.

Ministry of Education and Sports. MoES (2008). The Education Act. SUPPLEMENT No. 8 29th August, 2008. ACTS SUPPLEMENT to The Uganda Gazette No. 44 Volume Cl dated 29th August, 2008. Printed by UPPC, Entebbe, by Order of the Government. Accessed: September 10, 2010

Ministry of Education and Sports. MoES (2012). Education and Sports Sector Annual Performance Report-FY $2011 / 2012$ http://www.education.go.ug/data/mreports/27/EducationandSportsSectorAnnualPerformanceReport-FY2011/2012.html Accessed: November 13, 2013.

Ministry of Finance, Planning and Economic Development MFPED (2010). Millennium Development Goals Report for Uganda Special theme: Accelerating progress towards improving maternal health. http://www.unicef.org/uganda/Uganda_MDG_report_2010 final.pdf Accessed: November 21, 2011.

Obama, B. (2009). Address to joint session of Congress, the press office/Remarks-of-President-Barak-Obama-Address-to-Joint-Sessionof-Congress. http://www.whitehouse.gov/ Accessed: February 20, 2010.

Overseas Development Institute/Mokoro (2008). Sector budget support in practice: inception report. London: Overseas Development Institute.

Penny, A. Ward, M. Read, T \& Bines, H. (2008). Education sector reform: the Ugandan experience. International Journal of Education Development, 28(3): 268-285. 
Republic of Uganda Millennium Development Goals Report for Uganda (2010). http://www.undp.org/content/dam/undp/library /MDG/english/MDG\%20Country\%20Reports/Uganda/Uganda_MDGs_Report_2010.pdf Accessed: September 24, 2010.

Schultz, T. W. (1961). Investment in human capital. The American Economic Review, 1(2): 1-17.

Uganda Government npa.ug/wp-ontent/themes/npatheme/documents/vision2040.pdf accessed January 20, 2010.

Takahashi, S. \& Narahara, S. (2009). Ex-Post Evaluation of Japanese Technical Cooperation Project "Project on Support to the Improvement of School Management through Community Participation" The Republic of Niger: http://www2.jica.go.jp /en/evaluation/pdf/2009_0605403_4.pdf Accessed: September 21, 2010

Uganda Human Rights Commission (2004). Annual Report UHRC Kampala, Uganda.

UNESCO. (2010). Education for all global monitoring report 2010. Summary: Reaching the marginalised. United Nations: UNESCO Publishing. http://unesdoc.unesco.org/ images/0018/001865/186525E.pdf Accessed: March 10, 2010

UNESCO (2012) Education for All Global monitoring report: Youth and skills: Putting education to work. UNESCO Publishing. http://unesdoc.unesco.org/images/ 0021/002180/218003e.pdf Accessed: September 16, 2010

UNHS (2006) Education, http://www.unicef.org/infobycountry/uganda_statistics.html. Accessed July 02, 2009.

United Nations Office for the Coordination of Humanitarian Affairs Focus on Karamoja Special Report No.3 -October 2008 to January 2009. http://reliefweb.int/-report/-uganda/-uganda-ochaspecial report-no-3-focus-karamoja-oct-2008-jan-2009 Accessed September 10, 2010

Urry, J. (2000). "Metaphors". Sociology beyond societies: mobilities for the twenty-first century. New York: Routledge.

Uwezo (2010), Annual Learning Assessment Report. HIVOS. Open Society Institute, World Bank HUWELETT Foundation and Twaweza East Africa. http://www.uwezo.net/9234AAE1-0E8B-4AD2-9DC4-AD103A8C5F23/FinalDownload/Downloadld-B139DFA0927 FEDD051789FD175F4A876/9234AAE1-0E8B-4AD2-9DC4-AD103A8C5F23/wpcontent/uploads/2012/08/UG_2011_AnnualAssessment Report.pdf Accessed: August 8, 2012.

Wajdi, WB (2010). School Management Committees (SMCs). Http://blogs.worldbank.org /youthink/taxonomy/term/1221?page=3. Accessed October 20, 2010.

World Food Programme (2010) Fighting Hunger Worldwide. http://www.wfp.org /content /wfp-annual-report-2010-english Accessed December 20, 2011.

Zeitlin, A., Bategeka, L., Guloba, M., Kasirye, I \& Mugisha F. (2011). Management and motivation in Ugandan primary schools: Impact evaluation final report. http://www.pep-net.org/fileadmin/medias/pdf/files_events/9th_PEPNetworkConf/Papers-PEP_Program /Dec7-Session1-Madina-PIERI-11857.pdf Accessed January 2012. 